\title{
Audit Committee Characteristics and Accounting Conservatism: Does the Power of People Matter?
}

\begin{abstract}
Consistent with the prediction that political instability is strongly reflected in the performance of the economy, we examine whether the 2011 Egyptian Revolution mediates the association between audit committee characteristics and accounting conservatism. More specifically, we examine the association between five audit committee characteristics: independence, financial expertise, size, diligence, and members' multiple directorships and the levels and changes of accounting conservatism post the 2011 Egyptian Revolution. Using 205 firm-year observations between 2009 and 2013, we find evidence that audit committee independence, financial expertise, diligence, and members' multiple directorships (size) are positively (negatively) associated with accounting conservatism after the Egyptian Revolution. This result suggests a shift in the role played by audit committee members post the Egyptian Revolution. It lends support to the Developmental Democracy Theory, which emphasizes the power of people as responsible community citizens. The results in this study are robust to the use of alternative model specifications (e.g., an index for audit committee effectiveness, two stages regression, and a Propensity-Score Matching Sample).
\end{abstract}

Keywords: Corporate Governance, Audit Committee Characteristics, Accounting Conservatism, The Egyptian Revolution. 


\section{Audit Committee Characteristics and Accounting Conservatism: Does the Power of People Matter?}

\section{Introduction}

The Middle East has witnessed an outburst of political activities and civic movements, particularly in the countries where revolts successfully removed long-serving leaders and created new democratic social contracts (El Medni, 2013). By the end of 2011, the governments in Egypt, Tunisia, Libya, and Yemen were swept away by popular revolts, in an exceptional show of the power by the people. Although anecdotal evidence suggests that the power of people inspires professional organizations to take deliberate actions to reform the economy, the impact of the power of people on the Egyptian firm is unclear. On the one hand, according to the Developmental Democracy Theory (Sklar, 1987), the power of people creates a consortium of responsible citizens who transform the economy for the betterment of the wellbeing of its members. In line with this thought, Acemoglu, Hassan, and Tahoun (2018) find that the 500,000 protesters in Tahrir Square are associated with a lower market valuation of $0.8 \%$ of the firms connected to the incumbent group relative to non-connected firms. On the other hand, the cultural specificity approach (Abdelrahman, 2004) predicts that Democracy is unlikely to change the long-standing societal norms of oppression and that the society will not embrace the change. For example, the market response to the Revolution exhibits a negative reaction (e.g., the Egyptian stock market, following the revolution, lost more than 100 billion Egyptian pounds in 4 months, the main stock market index declined 30\%, while shares lost 103 billion, and Egyptians' remittances abroad decreased).

Nevertheless, anecdotal evidence suggests that the Egyptian Revolution has set the stage for the development of Corporate Governance (CG) best practices reforms. Since the outset of Mubarak's regime on January 2011, Egypt has witnessed a remarkable development in establishing the rules of corporate governance and the issuance of new registration, disclosure 
rules, and new standards (ex: corporate governance standards issued in 2011 and 2016). Likewise, corporate governance topic has received increased attention because of the increased direction of globalization of capital markets and the emphasis on the role of the private sector in the Egyptian economy. It is, therefore, expected that the proposed changes in the structure of the audit committee may improve their monitoring capabilities and effectiveness, which could influence the accounting conservatism practices. Although a few studies have been conducted to investigate the relation between corporate governance, in general, and accounting conservatism in the Egyptian context (e.g., Shahen, 2010; Nasr and Nitm, 2018, El-habashy, 2019), this study is the first to investigate the mediating effect of the 2011 Egyptian Revolution on the association between audit committee characteristics and accounting conservatism.

In supporting regulations and prior studies, the study focuses on the audit committee as a representative of internal governance mechanisms. During the SEC statement ${ }^{1}$ on December 30, 2019, on the Role of Audit Committees in Financial Reporting and Key Reminders Regarding Oversight Responsibilities, Chairman Jay Clayton mentions that: "Effective oversight by strong, active, knowledgeable and independent audit committees significantly furthers the collective goal of providing high-quality, reliable financial information to investors and our markets."

In agreement with corporate governance rationale, conservatism is one of the most prominent characteristics of financial accounting that has influenced accounting practices for centuries and is associated with the contracting role of accounting. Prior research (Kim and Zhang, 2016; Lara, Osma, and Penalva, 2012; Ahmed and Duellman, 2011) provides evidence that accounting conservatism is associated with positive firm outcomes (e.g., lower earnings

${ }^{1}$ The SEC (2019), Statement on Role of Audit Committees in Financial Reporting and Key Reminders Regarding Oversight Responsibilities. https://www.sec.gov/news/public-statement/statement-role-auditcommittees-financial-reporting. 
management, lower likelihood of stock market crash, fewer earnings forecasting errors and increase in future cash flow and gross margins). Therefore, accounting conservatism may signal a better monitoring and governance by the firm's directors. The study predicts that an adequate corporate governance system results in improving the monitoring role of management and consequently endorsing the implementation of conservative accounting to successfully achieve this role.

Anecdotal evidence suggests that economic reform cannot be separated from political and social reform. It is, therefore, expected that the 2011 Egyptian Revolution has been strongly reflected in the performance of the economy and the direction of the companies to apply certain policies as well. Since the 2011 Revolution, Corporate governance has received increased attention because of the increased direction of globalization of capital markets and the increasing importance of the role played by the private sector in the Egyptian economy. Based on the Egyptian governance codes and the reviewed empirical literature, it is expected that the proposed changes in the structure of the audit committee may improve the audit committee's monitoring capabilities and effectiveness which could influence the accounting conservatism practice. Although some studies have been conducted to investigate the relation between corporate governance and accounting conservatism in the Egyptian context (e.g.: Shahen, 2010; Nasr and Nitm, 2018), this study is the first to investigate the mediating effect of the 2011 Egyptian Revolution on this association.

This study discusses the effect of the internal governance system on conservatism practices around the Egyptian Revolution for companies listed in the Egyptian market. Audit committee characteristics are used as an internal governance mechanism including independence, financial expertise, diligence, size, and audit committee member's multiple directorships. Conservatism is measured using the Asymmetric Timeliness Model (AT, hereafter) applied by Khan and Watts (2009). This study proposes that, post-Egyptian Revolution, independent 
directors on the audit committee are more effective in monitoring the financial reporting process (Sharma and Kuang, 2014; Ghafran, 2013; Aanu, Odianonsen, and Foyeke, 2014). It further argues that, post-revolution, audit committees with financial expertise create effective monitoring functions (Badolato, Donelson, and Ege, 2014; Carcello, Neal, Palmrose, and Scholz, 2011), and that higher audit committee diligence reduces earning management and increases the quality of accounting information (Kang, Kilgore, and Wright, 2011; Suárez, García, Méndez, and Gutiérrez, 2013; Sultana, 2015). Although having a large audit committee is positively associated with higher earnings quality and negatively associated with the likelihood of engaging in downward earnings forecast guidance (Jennifer, Liu and Wang, 2014), the study suggests that smaller sizes audit committee post the Egyptian Revolution would be more efficient to the Egyptian firm to decrease the likelihood of engaging in heated debates and conflicts after a large exogenous market shock like the Revolution. Finally, audit committee members with multiple directorships are more experienced and have an extra monitoring mechanism that helps them perform their duties well (Sun, Liu and Lan, 2012). These factors would increase the demand for accounting conservatism in financial statements to constrain managers' opportunistic behaviors and will lead to improvements in the firm's governance structure.

Based on a sample of 205 firm-year observations of the 50 most active companies listed in the Egyptian stock market over the period 2009 to 2013 and retrieved from Egypt for Information Dissemination (EGID) database, the study conducts several analyses. The analyses provide support for the proposition that accounting conservatism levels and changes in Egypt are positively (negatively) affected by audit committee independence, financial expertise, frequency of meeting, members multiple directorships, and (size) after the revolution. More specifically, the study finds that after the 2011 Revolution, the audit committee size is negatively associated with accounting conservatism, while all other audit committee 
characteristics are positively associated with accounting conservatism, suggesting that the 2011 Egyptian Revolution strengthens the status of the audit committee. The study further develops an aggregate index of audit committee effectiveness to measure the effectiveness of the total quality of the firms' audit committee governance structure on accounting conservatism practices. The study provides evidence supporting the hypothesis that the Egyptian Revolution did cause a shift in the status and role played by audit committees in relation to accounting conservatism. The results are robust to multiple model specifications. For example, the study uses the level and changes in accounting conservatism, proxied by asymmetric timeliness, twostage regression analysis, and a Propensity-Score Matching Sample. The findings are consistent with prior studies, which suggest that accounting conservatism is related to stronger corporate governance mechanisms (Beekes, Pope, and Young, 2004; Ahmed and Duellman, 2007; Ahmed and Henry, 2012) following the 2011 revolution.

This study contributes to the nascent but growing literature on corporate governance and financial reporting quality in emerging markets in several ways. First, to the best of our knowledge, this is the first study that explores the Egyptian Revolution's mediating effect on corporate governance mechanisms specifically, audit committee effectiveness, on accounting conservatism. Additionally, it is the first study that investigates the effect of audit committee multiple directorships in the Egyptian context. Second, the results of this study help policymakers to evaluate best practices of the audit committees that fit the listed Egyptian companies. Third, this study contributes to concurrent debate on the impact of seismic political shifts on the effectiveness of corporate governance (e.g., EU and UK corporate governance law post Brexit). Finally, it is of interest to practitioners and policy makers who aspire to understand the process by which corporate governance evolves, factors that influence the company's use of accounting conservatism, and the controversial debate on the impact of corporate governance mechanisms on financial reporting quality. 
The rest of this paper is organized as follows. Section 2 introduces the related literature and develops hypotheses. Section 3 describes the sample selection and research design. Section 4 presents the empirical results. Finally, conclusion and suggestions for future research are provided in Section 5.

\section{Literature Review and Hypothesis Development}

\subsection{The Association between Audit Committee Characteristics and Accounting Conservatism}

Although conservatism and corporate governance have been studied separately in different studies, Beekes et al., (2004) is the first study that investigates the association between corporate governance and conservatism. Further, the relationship between corporate governance and accounting conservatism have been explored in different countries (e.g. Shahen, 2010; Kangarluei, Bayazidi, Tadeiyon, and Soleimani 2011; Nahandi, Hasanzadeh, Baghbani, and Astmal, 2012; Jarboui, 2013; Kootanaee, Seyyedi, Nedaei, and Kootanaee, 2013; Sharifi, Beydokhti, and Masroor, 2013; Dao, HassabElnaby, and Said, 2015). Two streams of research can be identified; the first one describes conservatism as a proxy for accounting quality or earnings quality through the asymmetric timeliness measure of conservatism. Research in this stream investigate the effect of corporate governance on accounting quality using conservatism as a measure. The other stream of research investigates the governance role of conservatism that can be proven through the substitutive relation (e.g. Hwang, Leveriza, Samson, and Sy, 2014) or the complementary relation (e.g. Foroghi, Amiri and Fallah, 2013). The studies in such a relationship also differ according to the corporate governance mechanisms used, conservatism measures, and the nature of the country the study applied in. Most studies in this field focus on the board of directors' characteristics as a proxy for corporate governance (e.g. Yunos, Smith, Ismail, and Ahmed, 2011). Whilst others focus on other mechanisms like ownership structure, audit committee and external auditor (e.g. Kangarluei et al. 2011; Nahandi, Hasanzadeh, Baghbani, and Astmal, 2012; Jarboui 2013; 
Sharifi et. al., 2013; Kiryanto, 2014). However, most of these studies examine this relationship in the US or the European context, leaving a gap in the literature related to studies that investigate the relationship between corporate governance and accounting conservatism in the Middle East and North Africa (MENA) region.

Corporate governance codes in many countries have empowered the audit committee's role in the oversight of financial reporting and ensuring high-quality accounting information. Through the 21 st century, an effective audit committee became the tool of the age to ensure the integrity of the financial reporting through monitoring the management and curb their tendency to manipulate earnings to match their interests. Therefore, the study focuses only on audit committee characteristics including independence, financial expertise, size, diligence, and members' multiple directorships as internal governance mechanisms and how it affects the level and the change of the accounting conservatism in the Egyptian context. The study focuses on these five audit committee characteristics for the following reasons.

First, empirical evidence shows that audit committee independent directors are associated with an improvement in the governance structure (Sharma and Kuang, 2014), the quality of financial reporting (Pomeroy and Thornton, 2008; Ghafran, 2013), timeliness of financial reports (Ebimobowel \& Vadirichukwu, 2013), and higher firm performance (Aanu et al., 2014). Few studies investigate the association between audit committee independence and conservatism level and find mixed results. A study by Mohammed (2010) in Malaysia reveals that the independence dimension of the board of directors and the audit committee is an important component of corporate governance that is promoting and positively associated with accounting conservatism. Other researchers such as (Lim, 2011; Hamdan, Al-Hayale, and Aboagela, 2012) contradict prior findings and reveal that audit committee independence is not significantly related to accounting conservatism. The study proposes that independent directors on the audit committee are more effective in monitoring the financial reporting process which 
likely will increase the demand for conservatism to constraint management opportunistic behaviors.

Second, Prior literature endorses the importance of having financial expertise amongst audit committee members by providing evidences that it increases their monitoring effectiveness (Carcello et al., 2011; Marzuki, Wahab, and Haron, 2016; Badolato et al., 2014; Aanu et al., 2014), reduces the accounting restatements (Carcello et al., 2011), associates with higher analyst forecast accuracy and lower dispersion (Abernathy, Herrmann, Kang, and Krishnan, 2013) and reduces earnings management (Badolato et al., 2014). More specifically, (Abernathy, 2010) find that adding accounting financial expertise to the audit committee is associated with an increase in the level of conservatism. In different contexts, (Hamdan et al., 2012; Marzuki et al., 2016; Sultana, 2015) find a positive association between audit committee financial experts and conservatism practices in Jordan, Malaysia, and Australia, respectively. Consistent with the literature, the study supports the proposition that expert audit committee members create effective monitoring function which probably increases the demand for conservatism.

Third, Audit committee diligence (proxied by the number of meetings) has been extensively viewed in the literature as an indicator of the audit committee's effectiveness (Suárez, 2013). For example, (Kang et al., 2011) find that higher audit committee meetings reduce the aggressiveness of the increasing manipulation of earnings. Likewise, (Liu and Zhuang, 2011) find that audit committee diligence increases the management forecast accuracy which consecutively increases the analysts' forecast accuracy and reduces dispersion. Also, (Ghafran, 2013) provides evidence that audit committee diligence improves audit quality and positively increase earnings quality. Recently, (Sultana, 2015) reports a positive association between accounting conservatism and the frequency of audit committee meetings in Australia, suggesting that audit committees act as effective monitoring mechanisms in restricting 
management's opportunistic behavior and overstatement of earnings. Based on the literature, the study proposes that having a diligent audit committee (e.g., meet frequently during the year) will lead to improvements in the firm's governance structure. Therefore, it is likely that diligent audit committees will use accounting conservatism to curb management opportunistic behavior.

Fourth, literature provides mixed evidence on the impact of audit committee size on financial reporting quality. On the one hand, larger audit committees have a greater chance of employing a combination of financial experts, which should increase the monitoring capability of the financial reporting, internal control process and earnings quality (Kent, Routledgea, and Stewar, 2010). On the other hand, (Mohd, 2011; Ghabayen, 2012) find no relation between audit committee size and firm performance. In the Egyptian context, a study conducted by (Reyad, 2011) reveals that the larger the audit committee size, the lower the probability of the company to get conservative audit report, and the higher the probability to get a clean audit report, which reflects higher quality for the financial reporting issued. Also, Soliman and Ragab (2014) find no significant relationship between audit committee size and earnings management (proxied by earnings management). Recently, The Egyptian Corporate Governance Code suggested that the minimum number of audit committee members should be three directors. Accordingly, the study recommends that a large audit committee is more efficient and cohesive in carrying out their monitoring function, which results in more conservative accounting practices. Finally, while multiple directorships members seem to be more experienced (Adeyemi, Okpala, and Dabor, 2012; De Vlaminck and Sarens, 2015) and may positively affect the function of audit committee (Gina, Kingsley, Vivian, and Eloho, 2013), it could be an indication of a busy committee (e.g., wearing multiple hats) and consequently attribute to less effective monitoring due to time limitation (Fields, Lowry, and Mkrtchyan, 2013), negatively impacting both the quality of reported earnings and audit fees as a measure for audit quality. 
Moreover, Sun, Liu and Lan (2014) find that audit committee members' multi-directorships are positively associated with real earnings management. This suggests that audit committees with multiple directorships are less effective in constraining earnings management. In Egypt, there is no evidence regarding the effectiveness of the multiple directorships, this study will be considered the first to test for such an association. The study argues that multiple directorships members negatively affect financial reporting quality and may open the room for poor financial reporting quality (weak corporate governance). This implies a negative relationship with the level of conservatism.

In general, the reviewed empirical evidence supports the proposition that the abovementioned audit committees' characteristics create an effective monitoring mechanism. Thus, the first testable hypothesis proposes that:

\section{H1: Audit committee characteristics are associated with accounting conservatism.}

2.2 The Mediating Effect of the Egyptian Revolution on the Association Between the Audit Committee Characteristics and Accounting Conservatism

Egypt's economy is one of the largest and most diverse in the Middle East and North Africa (MENA) region. It is also the most populous country in the MENA region and Africa with a population of over 100 million people and ranked the $14^{\text {th }}$ country worldwide (according to the 2020 census). ${ }^{2}$ This highlights the importance of a crucial improvement in the Egyptian economy. However, since the 2011 Revolution, the Egyptian economy witnessed challenging circumstances and a great shift. Gross Domestic Product (GDP) of Egypt grew by $1.8 \%$ in 2011 compared to that of 2010. The absolute value of GDP in Egypt rose \$17,702 million compared to 2010. The GDP per capita of Egypt in 2011 was $\$ 3,077$ compared to $\$ 2,922$ in 2010 (\$155 higher). As from the date of this shocking event, Egypt has witnessed a remarkable development in establishing the rules of corporate governance and the issuance of new

\footnotetext{
${ }^{2}$ http://worldpopulationreview.com/countries/egypt-population/
} 
registration, disclosure rules and introducing new standards (ex: corporate governance standards issued in 2011 and 2016) in line with international standards. Since the 2011 Revolution, Corporate governance has received increased attention because of the increased direction of globalization of capital markets and the increasing importance of the role played by the private sector in the Egyptian economy. To achieve that, the application of corporate governance international rules and regulations had been increased not only in the public sector, but also in the private sector as well.

The new governance structure published in 2011 requires that audit committees consist of at least three independent directors with one director who has knowledge and experience in both accounting and financial affairs. The audit committee is required also to meet at least once each quarter. Based on the governance codes and the reviewed empirical literature, it is expected that the proposed changes in the structure of the audit committee may improve the audit committee's monitoring capabilities and effectiveness which could influence the accounting conservatism practice.

In agreement with corporate governance rationale, conservatism is one of the most prominent characteristics of financial accounting that has influenced accounting practices for centuries and is associated with the contracting role of accounting. Literature shows that conservative reporting is effective in limiting managers' opportunistic behavior, reducing managers incentives to manage earnings (Lara, Osma and Penalya, 2012), enhancing firm value (Suijs, 2008; Watts and Zuo, 2011), and reducing the likelihood of a firms' future stock price crashes (Kousenidis, Ladas and Negakis, 2014; Kim and Zhang, 2016). Relatedly, conservatism reporting is also associated with an increase in the future cash flows and gross margins (Ahmed and Duellman, 2011). Because of the previously mentioned roles of accounting conservatism, it can be argued that it facilitates the monitoring role of accounting. Based on this argument, conservatism can be a useful tool for directors to fulfill their role of 
ratifying and monitoring choices and outcomes. Specifically, in line with the Developmental Democracy Theory, the study predicts that the Egyptian Revolution has increased the power given to audit committees in improving their monitoring role over management and consequently endorsing the implementation of conservative accounting to successfully achieve this role. To the best of our knowledge, no study examined the mediating effect of the Egyptian Revolution on the association between audit committee characteristics and accounting conservatisms. To fill this gap, following the literature, the study hypothesizes the following relationship:

\section{H2: The Egyptian Revolution mediates the association between audit committee characteristics and accounting conservatism.}

\section{Research Methodology}

\subsection{Sample Selection}

Data is restricted to listed firms in the Egyptian stock market for the following reasons. First, listed firms must conform to the exchange listing requirements that exist to enforce stability among companies. Second, one of the requirements to be listed is to have an audit committee, which is the focus of the study. Third, most corporate governance codes focus their attention on listed companies. Panel A of Table (1) displays the sample selection process. The study begins with the most active 50 companies listed in the Egyptian Stock Exchange during a five years sample period (2009-2013), and then removed one firm in the banking sector and eight more in the financial services sector. ${ }^{3}$ The final sample is composed of 41 firms (205 firm-years observations). Panel B of Table (1) shows sample distribution by industry. The final sample covers 12 industries including: 9.7\% from Basic Resources, 7.5\% Chemicals, 9.7\% Construction and Materials, 9.7\% Food and Beverage, 9.7\% Industrial Goods \& Services \&

\footnotetext{
${ }^{3}$ Banks and financial institutions are excluded from the sample because different governance regulations imposed by the Central Bank of Egypt.
} 
Automobiles, 2.5\% Media, 2.5\% Oil \& Gas, 19.5\% Personal and household products, $14.5 \%$ Real Estate, 5\% Travel \& Leisure, 2.5\% Technology, and 7.5\% Telecommunications.

Finally, the study imposes that a firm should have prior year date available to be included in the sample to estimate conservatism in an accumulated manner using the accrual-based measure. Therefore, data is collected from 2008 to 2014 to reflect the data required for the study period (2009-2013). 2009 is chosen to be the start date of the study according to the availability of data as it is unavailable to get financial data prior to 2008 through most companies' websites. This period also follows the effective date of the corporate governance code in Egypt (effective since 2004).

\section{[Insert Table (1) about here]}

\subsection{Data Collection}

To build the database for this study, several sources have been relied on, one main source is the EGID, which is a fully owned company by the Egyptian Exchange (EGX) and is the main provider of information about the Egyptian stock market. The study relies on secondary sources to acquire the required data about audit committee and conservatism proxies as follows; first, financial data required to calculate conservatism proxies (e.g. net income before extraordinary items, cash flow from operation, depreciation expenses, total assets, total liabilities, book value of equity, and number of shares outstanding) is extracted from the disclosure book, which reports data on all the financial information of the most active 50 companies from 2009 to 2011. The last disclosure book issued was for the year 2012 that contains information for the year ended 2011, therefore, the financial data for 2012 and 2013 have been collected manually through the annual reports published in companies' websites. The study obtains annual stock return data for the firms listed on EGX from www.mubasher.info.

Second, data on companies' audit committee characteristics are extracted from the audit committee report and the board of directors' profile. Some data also is collected from the 
corporate governance section in the company's annual reports, the webpage of each of the selected companies if available and other specialized websites which include databases of listed companies in the EGX. Data for audit committee member's multiple directorships is collected through reading each director's biography, searching the director's name in different searching engines and using specialized websites. ${ }^{4}$ If such information isn't available through the previously mentioned sources of data, data is collected by contacting the investor's relation officer of the company under study.

All previously mentioned relevant data has been collected for a period of five years from 2009 to 2013, except those used to compute conservatism accrual-based measure (net income before extraordinary items, cash flow from operation, depreciation expenses, total assets), it required additional figures from 2008 to 2014 as it is calculated in an accumulated manner.

\subsection{Variables Measurement}

The study includes audit committee characteristics as independent variables of interest that include the following five variables (independence, financial expertise, size, diligence, and multiple directorships). On the other side, accounting conservatism is used as the dependent variable of the study using two proxies: the asymmetric timeliness measure (Khan and Watts, 2009) and the accrual-based measure (Givoly and Hayn, 2000). In addition to the variables that are used to hypothesize the relationships, some control variables that are important in determining accounting conservatism in literature are also considered such as firm size, leverage, growth, auditor, and profitability.

More specifically, the audit committee characteristics is measured using five individual measures as follows: (1) Audit Committee Independence is measured as the percentage of independent members to total number of directors in the audit committee, (2) Audit Committee

\footnotetext{
4 Examples of the websites that the authors used to collect the data are www.4-traders.com, www.bloomberg.com, and www.quotes.wsj.com.
} 
Expertise is measured through the percentage of audit committee members with financial expertise to total directors in audit committee, (3) Consistent with prior research, the number of audit committee meetings held during the year has been used as a proxy for Audit Committee Diligence, (4) Audit Committee Size is measured as the total number of members of the audit committee at the year-end, and (5) Audit Committee Member's Multiple Directorship is measured as the median of the number of outside directorships held by audit committee directors. The median has the advantage of eliminating the extreme observations and reflecting the multiple directorships of most directors (Sarkar, J. and Sarkar, S., 2009). Second, the study uses two measures of conservatism; (1) asymmetric timeliness measure by Khan and Watts (2009) and (2) the accrual-based measure proposed by Givoly and Hayn (2000).

\subsubsection{Asymmetric Timeliness Measure:}

The study follows khan and Watts (2009) model to measure conservatism. Based on Basu (1997) model, Khan and Watts (2009) proposed a new measure for conservatism called the $C$-score model. This model is a firm-year measure of conservatism that takes into consideration both time-series and cross-sectional variations in conservatism through adding firm-specific characteristics (size, market to book ratio, and leverage) to the Basu regression model. The model specifies that both the timeliness of good news (which refers to as $G \_S c o r e$ ) and the incremental timeliness of bad news (which refers to as $C_{-}$Score) are linear functions of firm-specific characteristics. The total bad news timeliness is the sum of G_Score and C_Score. Combining the two models together, the following equation is presented:

$$
\text { Eit / Pit }-1=\beta_{0}+\beta_{1} R_{i t}+\beta_{2} D_{i t}+D_{i t} R_{i t}\left(\lambda_{0}+\lambda_{1} \text { Size }_{i t}+\lambda_{2} M / B_{i t}+\lambda_{3} L e v_{i t}\right)+\varepsilon_{i t}(1)
$$

Where: $i$ and $t$ denote firm and time period; $E_{i t} / P_{i t-1}$ is Net Income before extraordinary items divided by beginning of fiscal year market value of equity; $R$ is Fiscal year share return; $D_{i t}$ is Dummy variable equal (1) if returns are less than zero (negative) and (0) otherwise; $\beta_{1}$ measures the sensitivity of earnings to good news (good news timeliness) $; \beta_{1}+\beta_{2}$ measures the 
sensitivity of earnings to bad news (bad news timeliness) $\beta_{2}$ reflects the incremental sensitivity of earnings to bad news compared to good news (timeliness for bad news over good news). Size $_{i t}$ is the natural log of a firm's total assets; $M / B_{i t}$ is the market-to-book ratio; and Lev is the debt-to-equity ratio. In addition to the variables that are used to hypothesize the relationships, control variables that explain the variations in accounting conservatism are also considered such as firm size, leverage, growth, auditor, profitability, industry, and firm-fixed effect.

\subsubsection{Accrual-Based Measure of Conservatism}

The study also follows Givoly and Hayn's (2000) accrual-based model to measure conservatism. According to Givoly and Hayn (2000), a reverse pattern of accruals occurs when periods in which net income exceeds (falls below) cash flow from operation, is expected to be followed by periods with negative (positive) accruals. Givoly and Hayn (2000) examined the income statement effects of conservatism over time and conclude that conservative accounting leads to persistently negative accruals rather than the expected pattern of accrual reversals. Thus, a consistent predominance of negative accruals across firms over time is an indication of conservatism. The accrual-based measure of conservatism is computed as income before extraordinary items and discontinued operations (INC) plus depreciation expenses (DEPR) minus cash flows from operation (CFO) and deflated by total assets (TA). The accrual value is averaged over three-years centered at year $t$ the year of interest and referred to as CON_ACCR. Averaging over several years will mitigate the effects of any temporary large accruals since accruals are likely reversed within one to two years (Richardson, Sloan, Soliman, and Tuna, 2005). The CON_ACCR value above is derived after multiplying by -1 so that, a higher value of CON_ACCR indicates more conservatism. The equation is represented as follows:

$$
\begin{gathered}
\text { Accruals }_{t, 3}=\left[\left(I N C_{i j}+D E P R_{i j}-C F O_{i j}\right)\right] / T A_{i j} \\
\text { CON_ACCR } R_{i j}=\left(\text { Accruals }_{i j} / 3 \text { years }\right)
\end{gathered}
$$


Finally, the study controls for other firm-specific characteristics that may influence the relationship including firm size (SIZE), leverage (LEV), auditor (AUD), profitability (PROF) and growth (MTB). These variables are potentially associated with alternative motivations for accounting conservatism.

\section{Empirical Results}

\subsection{Descriptive Statistics}

Panel A of Table (2) provides descriptive statistics for a sample of 205 firm-year observations including means, standard deviation, maximum and minimum value. Results illustrate a high percentage of independence in the audit committee, at around $87 \%$. This indicates that most of the firms had complied with the requirement of the Egyptian code of corporate governance to have at least three independent non-executive directors on the audit committee. The financial expertise of the audit committee members (AC_EXP) across the sample period is about $48 \%$. The average number of audit committee meetings held per year (AC_DIL) is about five times (mean 5) which is consistent with prior literature (Soliman and Ragab, 2014) and (Amer et al., 2014). The descriptive statistics also show that the minimum number of meetings held annually by the audit committee is 2 and that the maximum number of meetings held annually is 12 . Based on the firm-year observations, $67 \%$ of the observations meet four times a year, followed by $11 \%$ of the observations meet five times a year.

The descriptive statistics suggest that the mean size for audit committees is approximately 3 members with a maximum number of 6 members. Regarding audit committee member's multiple directorships (AC_MULT), the statistic showed that, on average, the audit committee members had two or more outside directorships. Results indicate that the mean number of directorships held by the audit committee member is 2 . The results also show that the maximum number of directorships held by audit committee members is 5 , while the minimum number is zero which indicates that there are audit committees that do not possess 
this attribute. Regarding the accrual-based measure of conservatism (CON_ACCR), the mean value is 0.0027 , lower than the mean value (0.010) reported by Ahmed and Duellman (2007) for US firms. $58 \%$ of the sample of firms are audited by the big 4 audit firms and $10 \%$ of companies are related to industries that are highly litigious. To sum up, the descriptive analysis of this study shows that the Egyptian listed firms had successfully complied with the practices of corporate governance code announced in Egypt particularly concerning audit committees' requirements.

Panel B or Table (2) summarizes the statistical differences of firms with high versus low effective audit committee as measured by the audit committee index developed by the present study. ${ }^{5}$ Preliminary statistics suggest that firms with high audit committee governance index: (1) exhibit high conservatism using both proxies (CON_AT and CON_ACCR), the difference is, however, non-significant, (2) fall more pre- the Egyptian Revolution, (3) highly levered, (4) audited by big 4, (5) and larger than firms with low audit committee governance index.

\section{[Insert Table (2) about here]}

\subsection{Correlation Analysis}

Table (3) shows the Pearson and Spearman correlations between conservatism measures, audit committee characteristics, and control variables. The upper (lower) diagonal presents the Pearson (Spearman) correlations. As expected, according to the Pearson correlation four of the governance variables (audit committee independence AC_IND; audit committee financial expertise AC_EXP; audit committee diligence AC_DIL; audit committee size AC_SIZE are significantly and positively correlated (significance level is $1 \%$ ) to

\footnotetext{
${ }^{5}$ The audit committee governance index developed by the present study is an indicator variable equals one if the sum of the five audit committee indicator variables "these indicator variables are set to one if either AC_IND, AC_EXP, AC_DIL, AC_SIZE, and (AC_MULTI) is above (below) the sample median, zero otherwise" is above the sample median, zero otherwise.
} 
asymmetric timeliness (CON_AT) as a measure of accounting conservatism. According to both Spearman and Pearson correlations, the two measures of conservatism CON_AT and CON_ACCR are positively and significantly correlated (significance level is $1 \%$ and $5 \%$ for Pearson and Spearman correlations respectively). For the control variables and its relationship with conservatism, Profitability (PROF) is negatively correlated with CON_ACCR according to both Spearman and Pearson correlations. As expected, auditor AUD is positively correlated with CON_AT (significance level $1 \%$ and $5 \%$ for Spearman and Pearson correlations respectively). Results from both the CON_ACCR and CON_AT measures show a positive correlation with the Leverage variable (LEV) according to Spearman correlation. The audit committee frequency of meetings (AC_DIL) is positively and significantly correlated with audit committee size (AC_SIZE) and the absence of Multi-Directors (AC_MULTI) according to Spearman correlation. This suggests that audit committee diligence is possibly enhanced by increasing the size of the audit committee and the use of less busy members. The study also finds that audit quality (AUD) is positively correlated with accounting conservatism (CON_AT) at significance level 1\% and 5\% according to Spearman and Pearson correlation, Audit committee independence (AC_IND), audit committee diligence (AC_DIL) and audit committee expertise (AC_EXP). This relationship indicates that firms audited by big 4 audit firms demand more audit committee effectiveness through holding more frequency of audit committee meetings and possessing independent directors with accounting expertise. Both audit committee diligence (AC_DIL) and audit committee member size (AC_SIZE) are positively correlated with the market to book ratio (MTB) at significance level $1 \%$ according to both Spearman and Pearson correlations.

[Insert Table (3) about here]

\subsubsection{Estimating the Asymmetric Timeliness Measure of Conservatism (CON_AT)}


The study begins with testing (CON_AT) using Khan and Watts (2009) conservatism model based on equation (1) previously presented in section (3.3.1). Table 4 shows the results of regressions of earnings on the variables listed. As previously explained in equation (1), $\mathrm{E}_{\mathrm{i}} / \mathrm{P}_{\mathrm{it}-}$ 1 and $\mathrm{R}_{\mathrm{it}}$ are estimated on a three-year backward accumulation. The study runs the regression using a one-year estimate of asymmetric timeliness.

The regression result shows that the relation between earnings and returns, as represented by the coefficients of $\mathrm{R}$ is significantly positive as expected. The coefficient of R_SIZE is significantly negative as predicted, consistent with larger firms having lower good news timeliness (or being more conservative). The coefficient of DR_Size is significantly positive as predicted, consistent with the evidence that large firms have higher asymmetric timeliness. LaFond and Watts (2008) suggest that less conservative firms have higher-good news timeliness and lower-asymmetric earnings timeliness. The regression results also show that the coefficient of R_MTB is negative but insignificant. The coefficient of DR_MTB is significantly positive, which means that growth firms having higher asymmetric timeliness, which is inconsistent with the study's predictions. The coefficient of R_Lev is significantly negative. Besides, the coefficient of DR_Lev is significantly positive as predicted, suggesting that more leveraged firms have higher asymmetric earnings timeliness. The parameter estimates obtained from the regression model of equation (1) are used to calculate the C_Score which represents the firm-year asymmetric timeliness conservatism measure (CON_AT).

\section{[Insert Table (4) about here]}

\subsubsection{Results on the Association between Accounting Timeliness and Audit Committee}

\section{Characteristics.}

The main study regression model is employed to test the effect of five audit committee characteristics (1) AC_IND: Proportion of independent directors to total directors on audit committee, (2) AC_EXP: Proportion of audit committee members with financial expertise to 
total directors on audit committee, (3) AC_DIL: Numbers of audit committee meetings held per year, (4) AC_SIZE: Number of members of audit committee elected by board of directors (5) AC_MULTI: The median of the number of outside directorships held by audit committee directors) on asymmetric timeliness (CON_AT). Control variables included in this model are auditor (AUD), profitability (PROF), industry categories (IND_CAT) and firm-fixed effect (FIXED-EFF). Firm size, leverage, and market to book ratio are excluded to avoid duplication as they are included in (Khan and Watts, 2009) regression model.

Table (5) displays the results of five regression models on the association between CON_AT and individual measures of audit committee. Model (1) suggests that AC_IND is significantly and positively associated with CON_AT at $1 \%(\beta=0.276)$. The model is statically significant and explains $22.5 \%$ of the variations of CON_AT. Likewise, the results in Models (2) through (5) suggest a strong association between CON_AT and the rest of the proxies of audit committee quality (AC_EXP, AC_DIL, AC_SIZE, and AC_MULTI). All models are statistically significant and explain $22.5 \%-35.4 \%$ of the variations of CON_AT. For example, Model (2) suggests that AC_IND and AC_EXP are significantly and positively associated with CON_AT at $1 \%$ ( $\beta_{1}$ and $\beta_{2}=0.0306$ and 0.0160 respectively $)$. The model is statically significant and explains $25.4 \%$ of the variations of CON_AT. Model (3) suggests that AC_IND, AC_EXP and $\mathrm{AC} \_D I L$ are significantly and positively associated with CON_AT at $1 \%\left(\beta_{1}, \beta_{2} \& \beta_{3}\right.$ $=0.0253,0.0143$, and 0.0041 respectively). The model is statically significant and explains $33.4 \%$ of the variations of CON_AT. Model (4) suggests that AC_IND, AC_EXP, AC_DIL, and AC_SIZE are significantly and positively associated with CON_AT at $1 \%\left(\beta_{1}, \beta_{2}, \beta_{3}\right.$ and $\beta_{4}=0.0232,0.0133,0.0036$ and 0.0030 respectively). The model is statically significant and explains $34.1 \%$ of the variations of CON_AT. Model (5) suggests that AC_IND, AC_EXP, AC_DIL, and AC_SIZE are significantly and positively associated with CON_AT at $1 \%\left(\beta_{1}\right.$, $\beta_{2}, \beta_{3}$ and $\left.\beta_{4}=0.0219,0.0123,0.0034,0.0047\right)$. Model (5), however, shows that AC_MULTI is 
negatively and significantly associated with CON_AT at $1 \%\left(\left(\beta_{1}=-0.0026\right)\right.$. The model is statically significant and explains $35.4 \%$ of the variations of CON_AT. Overall, the results in this section support the first research hypothesis and suggest a significant association between audit committee characteristics and accounting conservatism as proxied by accounting timeliness.

\section{[Insert Table (5) about here]}

\subsubsection{Results on the Association between Accounting-Based Accruals and Audit Committee} Quality Index Post the Egyptian Revolution

To test the second research hypothesis on the association between asymmetric timeliness as a measure of accounting conservatism and audit committee characteristics post the Egyptian Revolution, the study adds the interaction term the Egyptian Revolution (REV) to audit committee characteristics. Model (1) in Table (6) summarizes the results on the association between the interaction term REV and individual audit committee characteristics and the level of (CON_AT) as proxied by asymmetric timeliness. Model (2) in Table (6) summarizes the results on the association between the interaction term REV and individual audit committee characteristics and the $\left(\triangle \mathrm{CON} \_\mathrm{AT}\right)$ as proxied by $\Delta$ in asymmetric timeliness. As shown in Table (6), the interaction terms (AC_IND_REV, AC_EXP_REV, AC_DIL_REV, AC_MULTI_REV) in Model (1) are positively and statistically significantly associated with CON_AT at $1 \%\left(\beta_{1}, \beta_{2}, \beta_{3}\right.$ and $\beta_{5}=0.1078,0.0033,0.0283$ and 0.0417 respectively $)$. This result suggests that the audit committee's status and effectiveness are strengthened post the Egyptian Revolution. The coefficient of the interaction term AC_SIZE_REV is, however, negative, and statistically significant at $1 \%\left(\beta_{1}=-0.0548\right)$, indicating that a large audit committee post the Egyptian Revolution is contributing to decreasing the accounting conservatism and possibly undesirable. This result makes sense given that larger audit committee may end up with more debate and disagreement among members while 
smaller/medium-sized audit committees may be more beneficial to the Egyptian firm post a period of turmoil and rebel. Model (2) in Table (6) shows the almost similar direction and significance of association as those shown in Model (1), except that AC_EXP_REV is negative and statistically insignificant in only Model (1). The results in Model (2) controls for the endogeneity between audit committee characteristics and accounting conservatism to rule out the possibility that firms with high accounting conservatism are likely to hire audit committee with certain characteristics.

\section{[Insert Table (6) about here]}

The study repeated the analysis in Table (6) by using the aggregate measure of audit committee characteristics (GOV_SC) following Abernathy (2010) and employing the interaction term REV and GOV_SC as the measure of interest (REV_GOV). GOV_SC is a measure of the quality of the internal corporate governance code. The study composed GOV_SC from the five individual audit committee characteristics used in the main analysis. GOV_SC is a continues variable that equals the sum of five audit committee indicator variables. These indicator variables are set to one if either AC_IND, AC_EXP, AC_DIL, AC_SIZE, and (AC_MULTI) is above (below) the sample median, zero otherwise. Model (1) in Table (7) summarizes the results on the association between the interaction term REV and audit committee index (GOV_SC) and the level of accounting conservatism as proxied by asymmetric timeliness. The variable of interest in Model (1) is the interaction term (REV_GOV). Model (2) in Table (7) summarizes the results on the association between the interaction term REV and audit committee index (GOV_SC) and changes in accounting conservatism ( $\triangle$ CON_AT) as proxied by asymmetric timeliness. The variable of interest in Model (2) is the interaction term (REV_GOV). As shown in Model (2) in Table (7), there is a positive and statistically significant association at a $10 \%$ significance level between REV_GOV and $\Delta$ CON_AT $\left(\beta_{1}=0.0161\right)$. The association between REV_GOV and the level 
of asymmetric timeliness (CON_AT) is negative but non-significant as presented in Model (1) of Table (7). The results in this table, overall, support the results in Table (6) that the Egyptian Revolution did have a positive impact on the audit committee status and effectiveness.

\section{[Insert Table (7) about here]}

\subsection{Additional Analyses}

\subsubsection{Results on the Association between Level and Change in Accruals-based Accounting} Conservatism and Audit Committee Quality Index

While the first research hypothesis suggests an association between accounting conservatism and audit committee characteristics, it is likely for firms with a high level of accounting conservatism to choose to hire an audit committee with certain characteristics to make sure that the quality of accounting information is maintained. This latter assumption challenges the premise that audit committee affects accounting conservatism and suggests an endogenous association between audit committee quality and accounting conservatism. To rule out the possibility that accounting conservatism affects the audit committee and to validate the results in Table (5), the study regresses the levels and changes of accrual-based accounting conservatism (CON_ACCR) on an aggregate measure of audit committee quality (GOV_SC). The change model highlights the incremental contribution of audit committee quality metric on accounting conservatism.

The following empirical model is employed to test the effect of audit committee characteristics on the levels and changes in accrual-based conservatism measure (CON_ACCR). The accrual-based measure of conservatism CON_ACCR is calculated according to equation (2 and 3) that presented in section (3.3.2) proposed by Givoly and Hayn (2000). The regression model also includes control variables which might influence accrual based as a measure of accounting conservatism namely firm size (SIZE), leverage (LEV), growth (MTB), auditor (AUD) and profitability (PROF). The results (untabulated) suggest 
strong positive and significant associations at $1 \%$ significance level between the levels and changes in accrual-based accounting (ACCR, $\triangle$ ACCR) and the audit committee index (GOV_SC) with the following coefficients respectively $\left(\beta_{1}\right.$ and $\beta_{1}=0.0218$ and 0.0233$)$. Both models are statistically significant at $1 \%$ and explain $10 \%$ and $40 \%$ respectively of the variations in accrual-based measure of accounting conservatism. The results in this section provide support to $\mathrm{H} 1$ and provide internal validity to the main proxy used as a measure of accounting conservatism.

\subsubsection{Two-Stages Regression of Asymmetric Timeliness on Audit Committee Characteristics}

The study further employs a two-stages Least Squares Regression Analysis to provide evidence on the association between audit committee characteristics and accounting conservatism in the Egyptian settings. The study uses Market to Book ratio (MTB) as an instrumental variable because it is likely to be correlated with audit committee index but not accounting conservatism. Table (9) presents the results of the two-stages Least Squares Analysis. Model (1) displays the results on the first stage regression of the Audit Committee Score as an indicator variable (GOV_SC_IND) that equals 1 if Gov_SC is higher than the sample median, zero otherwise on MTB as an instrumental variable. Other control variables are also included in the first stage regression. Model (2) displays the results of the second-stage regression of Asymmetric Timeliness (CON_AT) on the predictive value of predicted value of audit committee score index (P_Gov_SC) from the first stage regression as the variable of interest in addition to other control variables. As shown in Model (1) in Table (9), GOV_SC is positively and significantly associated with the control variables and the model is statistically significant at $1 \%$ and explains $32.4 \%$ of the variations in GOV_SC. As expected, the predicted value of GOV_SC (P_GOV_SC) that are derived from Model (1) is shown in Model (2) to have a significant and positive association with CON_AT at $1 \%\left(\beta_{1}=0.2023\right)$. The model is statistically significant at $1 \%$ and explains $25.4 \%$ of the variations of CON_AT. Overall, the 
results in this section support the first research hypothesis that audit committee characteristics are associated with accounting conservatism.

\section{[Insert Table (9) about here]}

\subsubsection{Propensity-Score Matching Regression of Asymmetric Timeliness on Audit Committee} Characteristics

The study also employs a Propensity-Score Matching sample of firms with high versus low audit committee index and reexamine the association between accounting conservatism and audit committee characteristics. The study uses 1:1 matching with caliber 0.22 . The common level of support is between $0.08-0.65$ and of the 145 observations in the control group, 142 is within the support region. The study uses a Logistic Regression of Audit Committee Governance Score Indicator (GOV_Score_IND) on firm-specific characteristics such as LEV, AUDITOR, PROF, SIZE, and MTB. The regression of CON_AT on Audit Committee Characteristics (AC_IND, AC_EXP, AC_DIL, AC_SIZE, AC_MULTI) using a PropensityScore Matching Sample of firms was conducted. The (untabulated) results show that audit committee index (GOV_SC_IND), which is represented in a dummy variable that equals 1 if the GOV_SC is higher than the sample median, zero otherwise, is significantly associated with audit quality (AUD) and profitability (PROF) at $1 \%$ and $10 \%$ respectively $\left(\beta_{1}\right.$ and $\beta_{2}=6.5196$ and 2.0682). The model is statistically significant at $1 \%$ with a Likelihood Ratio 20.1495 and Pseudo R square 9.4\%. The results are in line with the expectations except that AC_EXP and AC_DIL are although positively associated with CON_AT, the association is non-significant. AC_IND, and AC_SIZE (AC_MULTI) are significantly and positively (negatively) associated with CON_AT at $5 \%$ and $1 \%(1 \%)$ respectively with $\beta_{1}$ and $\beta_{2}=0.0229$ and $0.0181\left(\beta_{5}=-\right.$ $0.0155)$ respectively. 


\section{Conclusion and Future Avenues}

The study attempts to understand the effect of internal corporate governance mechanisms, proxied by the audit committee characteristics, on the level and changes of the accounting conservatism. Moreover, the study further examines the mediating effect of the Power of People, proxied by an exogenous event such as the Egyptian Revolution, on the association between audit committee characteristics and accounting conservatism. The study focuses on five characteristics of audit committee including independence, financial experts, diligence, size, and multiple directorships. The study suggests that audit committees that are dominated by independent directors, more effective, are likely to have the power to employ conservative accounting as a tool for monitoring managers' decision making and strict managers willing to use aggressive or less conservative accounting. The study also suggest that audit committee financial expertise constrains managers' opportunistic behavior through incorporated bad news in earnings in a timelier manner (higher conservatism). Moreover, the results provide evidence to support a positive relationship between the audit committee meetings frequency (diligence) and conservatism. Moreover, the study finds that while the audit committee size (audit committee multi-directorship) is positively (negatively) associated with accounting conservatism for the overall sample of firms, the results are reversed post the Egyptian Revolution. This latter result indicates that the Egyptian market does benefit from multi- directorships (busy directors) and would benefit more from the expertise of these directors post the Egyptian Revolution. Likewise, it seems that smaller audit committee sizes are more beneficial to the Egyptian firms post the Revolution, possibly because they can conduce the necessary oversight and monitoring functions with less conflict. Finally, for the audit committee aggregate index, the result supports the complementary effect between corporate governance and accounting conservatism suggesting that conservatism can be used as a governance tool. The results after interjecting the Egyptian Revolution is consistent with 
the need for expertise post the Revolution by utilizing the expertise of busy directors and further stresses on the focus on smaller committee size as a more effective option, perhaps to limit the debate, than a larger one.

The results are robust to multiple specifications. For example, the study uses the level and changes in accounting conservatism, proxied by asymmetric timeliness and accrual-based accounting, two-stages regression analysis, and Propensity-Score Matching Sample. The findings are consistent with prior studies and showing that accounting conservatism is related to stronger corporate governance mechanisms (Beekes et al., 2004; Ahmed and Duellman, 2007; Ahmed and Henry, 2012).

Future research may be undertaken and extended to include the relationship between conservatism and other corporate governance mechanisms rather than audit committee (whether internal or external) such as the board of directors, internal audit, external auditor in the Egyptian context. Furthermore, given the institutional environment in Egypt, future research may examine the effect of block shareholding, and government ownership on accounting conservatism. Additionally, the moderating effects of these variables on the relationship between the audit committee and conservatism can be explored. 


\section{Appendix A: Variable Definition and Measurements}

\begin{tabular}{|c|c|c|}
\hline Variables & Symbol & Definition and Measurements \\
\hline \multicolumn{3}{|c|}{ Independent Variables: Audit Committee Characteristics } \\
\hline $\begin{array}{l}\text { Audit Committee } \\
\text { Independence }\end{array}$ & AC_IND & $\begin{array}{l}\text { Proportion of independent directors to total directors on audit } \\
\text { committee. }\end{array}$ \\
\hline $\begin{array}{l}\text { Audit Committee } \\
\text { Financial Expertise }\end{array}$ & AC_EXP & $\begin{array}{l}\text { Proportion of audit committee members with financial expertise } \\
\text { to total directors on audit committee }\end{array}$ \\
\hline $\begin{array}{l}\text { Audit Committee } \\
\text { Diligence }\end{array}$ & AC_DIL & Numbers of audit committee meetings held per year \\
\hline Audit Committee Size & AC_SIZE & $\begin{array}{l}\text { Number of members of audit committee elected by board of } \\
\text { directors }\end{array}$ \\
\hline $\begin{array}{l}\text { Audit Committee } \\
\text { Member's Multiple } \\
\text { Directorship }\end{array}$ & AC_MULT & $\begin{array}{l}\text { The median of the number of outside directorships held by audit } \\
\text { committee directors }\end{array}$ \\
\hline $\begin{array}{l}\text { Audit Committee Index } \\
\text { Value }\end{array}$ & GOV_SC & $\begin{array}{l}\text { A continues variable that equals the sum of five audit committee } \\
\text { indicator variables. These indicator variables are set to one if } \\
\text { either AC_IND, AC_EXP, AC_DIL, AC_SIZE, and } \\
\text { (AC_MULTI) is above (below) the sample median, zero } \\
\text { otherwise. }\end{array}$ \\
\hline $\begin{array}{l}\text { Audit Committee Index } \\
\text { Indicator }\end{array}$ & GOV_SC_IND & $\begin{array}{l}\text { An indicator variable that equals one of GOV_SC is above the } \\
\text { sample median, zero otherwise. }\end{array}$ \\
\hline The Egyptian Revolution & REV & $\begin{array}{l}\text { An indicator variable that equals one for years 2012, and } 2013 \\
\text { (post the Egyptian Revolution), zero otherwise. }\end{array}$ \\
\hline \multicolumn{3}{|c|}{ Dependent Variable: Accounting Conservatism } \\
\hline $\begin{array}{l}\text { Asymmetric Timeliness } \\
\text { Conservatism }\end{array}$ & CON_AT & $\begin{array}{l}\text { It represents a regression between earnings and return where, } \\
\text { earnings represented Net Income before extraordinary items } \\
\text { deflated by beginning of fiscal year market value of equity and } \\
\text { Stock Return were calculated as buy and hold stock return } \\
\text { (based on stock price). }\end{array}$ \\
\hline $\begin{array}{l}\text { Accrual Based } \\
\text { Conservatism }\end{array}$ & CON_ACCR & $\begin{array}{l}\text { (net income before extraordinary items plus depreciation } \\
\text { expense less cash flow from operations) scaled by total assets, } \\
\text { averaged over a three-years period centered on the year of } \\
\text { interest and multiplied by }-1\end{array}$ \\
\hline \multicolumn{3}{|l|}{ Control Variables } \\
\hline Firm Size & SIZE & The natural logarithm of total assets. \\
\hline Leverage & LEV & The ratio of total debt to total equity \\
\hline Profitability & PROF & Cash flow from operation divided by total assets. \\
\hline Growth & MTB & $\begin{array}{l}\text { Market to book ratio (Market value of equity divided by Book } \\
\text { value of equity) }\end{array}$ \\
\hline Auditor & AUD & $\begin{array}{l}\text { Is a dummy variable, assigned the value (1) for the firm audited } \\
\text { by big } 4 \text { audit firm and (0) otherwise }\end{array}$ \\
\hline Industry Categorization & IND_CAT & $\begin{array}{l}\text { Twelve indicator variables to represent the industry } \\
\text { categorization. }\end{array}$ \\
\hline Firm-Fixed Effect & FIXED_EFF & Six indicator variables to proxy for the firm-fixed effect. \\
\hline
\end{tabular}




\section{Appendix B: Audit Committee Aggregate Index}

In this section, the study develops an aggregate index for audit committee characteristics to measure the total level or quality of firms' audit committee governance characteristics. The aggregate index has been developed following the method of (Abernathy, 2010). The index incorporates several characteristics of the structure of audit committee as the following:

- AC_IND: a dummy variable that equals 1 if the proportion of independent directors in audit committee is greater than the sample median, and 0 otherwise.

- AC_EXP: a dummy variable that equals 1 if the audit committee proportion of financial expertise directors is greater than the sample median, and 0 otherwise.

- AC_DIL: a dummy variable that equals 1 if the audit committee meeting frequency is greater than the sample median, and 0 otherwise.

- AC_SIZE: a dummy variable that equals 1 if the board size is higher than the sample median, and 0 otherwise.

- AC_MULTI: a dummy variable that equals 1 if the number of outside directorships held by audit committee directors is lower than the sample median, and 0 otherwise.

The study uses the variable (GOV) to represent a summary measure of corporate governance that equal the sum of the previously mentioned five audit committee governance variables: $A C_{-} I N D, A C \_E X P, A C \_D I L, A C \_S I Z E$, and $A C_{-} M U L T I$. After that, the study uses a dummy variable that equals 1 if GOV is greater than the sample median and 0 otherwise. In other words, the sample is divided into strong governance firms $\left(\mathrm{GOV} \_\mathrm{SC}=1\right)$ and weak governance firms $\left(\mathrm{GOV} \_\mathrm{SC}=0\right)$.

Two regression models are developed to estimate the effect of aggregate index of audit committee characteristics on conservatism practice for the Egyptian listed companies using (Khan and Watts, 2009) asymmetric timeliness conservatism measure (CON_AT) in the first regression and the accrual-based conservatism measure (CON_ACCR) in the second regression. 


\section{References:}

Aanu, O., Odianonsen, I., \& Foyeke, O., (2014), Effectiveness of Audit Committee and Firm Financial Performance in Nigeria: An Empirical Analysis, Journal of Accounting and Auditing: Research and Practice, 2014, 1-11. doi: 10.5171/2014. 301176.

Abdelrahman, M., (2004), Civil Society Exposed, the Politics of NGOs in Egypt. Cairo: AUC Press in Cairo.

Abernathy, J., (2010), Three Essays on Audit Committees and Financial Reporting Quality, $\mathrm{PhD}$ Dissertation, Alabama University.

Abernathy, J., Herrmann, D., Kang, T., \& Krishnan, G., (2013), Audit Committee Financial Expertise and Properties of Analyst Earnings Forecasts, Advances in Accounting, 29(1), 111.

Acemoglu, D., Hassan, T.A. \& Tahoun, A., (2018). The power of the street: Evidence from egypt's arab spring. The Review of Financial Studies, 31(1), 1-42.

Adeyemi, S., Okpala, O., \& Dabor, E., (2012), Factors Affecting Audit Quality in Nigeria, International Journal of Business and Social Science, 3(20), 198-209.

Ahmed, A., \& Duellman, S., (2007), Accounting Conservatism and Board of Director Characteristics: An Empirical Analysis, Journal of Accounting and Economics, 43(2-3), 411-437.

Ahmed, A., \& Duellman, S., (2011), Evidence on The Role of Accounting Conservatism in Monitoring Managers' Investment Decisions, Accounting and Finance, 51(3), 609-633.

Ahmed, K., \& Henry, D., (2012), Accounting Conservatism and Voluntary Corporate Governance Mechanisms by Australian Firms, Journal of Accounting and Finance, 52(3), 631-662.

Amer, M., Ragab, A. A., \& Shehata, S. E. (2014). Audit Committee Characteristics and Firm Performance: Evidence from Egyptian Listed Companies, (June).

Badolato, P., Donelson, D., and Ege, M., (2014), Audit Committee Financial Expertise and Earnings Management: The Role of Status, Journal of Accounting and Economics, 58 (2/3), 208-230.

Basu, S., (1997), The Conservatism Principle and The Asymmetric Timeliness of Earnings, Journal of Accounting and Economics, 24(1), 3-37.

Beekes, W., Pope, P., \& Young, S., (2004), The Link between Earnings Timeliness, Earnings Conservatism and Board Composition: Evidence from the U.K, Corporate Governance: An International Review, 12(1), 47-59.

Carcello, J., Neal, T., Palmrose, Z., \& Scholz, S., (2011), CEO Involvement in Selecting Board Members, Audit Committee Effectiveness, and Restatements, Contemporary Accounting Research, 28(2), 396-430.

Dao, M., HassabElnaby, H., \& Said, A., (2015), The Impact of Audit Committee and Shareholder Activism on the Association between Audit-Firm Tenure and Accounting Conservatism, Accounting and Finance Research, 4(1), 112-128.

De Vlaminck, N., \& Sarens, G., (2015), The Relationship Between Audit Committee Characteristics and Financial Statement Quality: Evidence from Belgium, Journal of Management and Governance, 19(1), 145-166.

Ebimobowel, A., \& Yadirichukwu, E., (2013), Audit Committee and Timeliness of Financial Reports: Empirical Evidence from Nigeria, Journal of Economics and Sustainable Development, 4(20), 14-26.

El Medni, Bakri M. (2013). Civil Society and Democratic Transformation in Contemporary Egypt: Premise and Promises., International Journal of Humanities and Social Sciences, 3(12), 14-26.

El-habashy, H. A. (2019). The Effect of Corporate Governance Attributes on Accounting Conservatism in Egypt. Academy of Accounting and Financial Studies Journal. 
Fields, L., Lowry, M., \& Mkrtchyan, A., (2013), Are Busy Boards Detrimental? Journal of Financial Economics, 109(1), 63-82.

Foroghi, D., Amiri, H., \& Fallah, Z., (2013), Corporate Governance and Conservatism, International Journal of Academic Research in Accounting, Finance and Management Sciences 3(4), 61-71.

Ghabayen, M., (2012), Board Characteristics and Firm Performance: Case of Saudi Arabia, International Journal of Accounting and Financial Reporting 2(2), 168-200.

Ghafran, C., (2013), Audit Committees and Financial Reporting Quality, PhD Thesis, Sheffield University.

Gina, O., Kingsley, O., Vivian, O., \& Eloho, A., (2013), The Role of Audit Committee in Enhancing Financial Reporting in Nigeria, Journal of Business and Management 13(1), 27-34.

Givoly, D., \& Hayn, C., (2000), The Changing Time-Series Properties of Earnings, Cash Flows and Accruals: Has Financial Reporting Become More Conservative? Journal of Accounting and Economics, 29(3), 287-320.

Hamdan, A., Al-Hayale, T., \& Aboagela, E., (2012), The Impact of Audit Committee Characteristics on Accounting Conservatism: Additional Evidence from Jordan, Journal of King Saud University-Administration sciences, 24(1), 1-15.

Hwang, C., Leveriza, H., Samson, R., \& Sy, S., (2014) Contrast of Perspectives: The Role of Corporate Governance Structures on Conservative Behavior of Philippine Publicly Listed Firms, The De La Salle University (DLSU) Research Congress (March, 2014), Manila, Philippines.

Jarboui, A., (2013), An Empirical Examination of the Relationship between Board of Director Composition, Ownership Structure and Accounting Conservatism, International Journal of Economics, Finance and Management Sciences, 1(6), 273-284.

Jennifer, L., Liu, C., \& Wang, X., (2014), To What Extent Does the Audit Committee Curb Downward Earnings Forecast Guidance? Review of Accounting and Finance, 13(2), 110133.

Kang, W., Kilgore, A., \& Wright, S., (2011), The Effectiveness of Audit Committees for Lowand Mid-Cap Firms, Managerial Auditing Journal, 26(7), 623-650.

Kangarluei, S., Bayazidi, A., Tadeiyon, S., \& Soleimani, B., (2011), Corporate Governance Mechanisms and Conservatism: The Evidence from Iran, International Journal of Academic Research, 3(1), 592-601.

Kent, P., Routledgea, J., \& Stewar, J., (2010), Innate and Discretionary Accruals Quality and Corporate Governance, Journal of Accounting and Finance, 50(1), 171-195.

Khan, M., \& Watts, R., (2009), Estimation and Empirical Properties of a Firm-Year Measure of Accounting Conservatism, Journal of Accounting and Economics, 48(2/3), 132-150.

Kim, J., \& Zhang, L., (2016), Accounting Conservatism and Stock Price Crash Risk: FirmLevel Evidence, Contemporary Accounting Research, 33(1), 412- 441.

Kiryanto (2014), Analysis of The Characteristics Audit Committee on Earnings Quality, International Journal of Business, Economics and Law, 4(1), 31-37.

Kootanaee, A., Seyyedi, J., Nedaei, M., \& Kootanaee, M., (2013), Accounting Conservatism and Corporate Governance's Mechanisms: Evidence from Tehran Stock Exchange, International Journal of Economics, Business and Finance, 1(10), 301-319.

Kousenidis, D., Ladas, A., \& Negakis, C., (2014), Accounting Conservatism Quality of Accounting Information and Crash Risk of Stock Prices, Journal of Economic Asymmetries, 11, 120-137.

LaFond, R., \& Watts, R., (2008), The Information Role of Conservatism, The Accounting Review, 83(2), 447-478. 
Lara, J. M. G., Osma, B. G., \& Penalva, F. (2012). Accounting conservatism and the limits to earnings management. Available at SSRN: http://ssrn.com/abstract=2165694

Lim, R., (2011), Are Corporate Governance Attributes Associated with Accounting Conservatism? Accounting and Finance, 51(4), 1007-1030.

Liu, M., \& Zhuang, Z., (2011), Management Earnings Forecasts and the Quality of Analysts' Forecasts: The Moderating Effect of Audit Committees, Journal of Contemporary Accounting and Economic, 7(1), 31-45.

Marzuki, M. M., Wahab, E. A. A., \& Haron, H. (2016). Corporate governance and earnings conservatism in Malaysia. Accounting Research Journal.

Mohammed, N., Ahmed, K., and Ji, X., (2010) Accounting Conservatism, Corporate Governance and Political Influence: Evidence from Malaysia, Working Paper, La Trobe University.

Mohd Azmi, M. N. (2011). The Effect of Implementation of Malaysian Code of Corporate Governance (MCCG) 2007 on Corporate Governance Attributes and Financial Performance (Doctoral dissertation, Universiti Utara Malaysia).

Nahandi, Y., Hasanzadeh, R., Baghbani, S., \& Astmal, M., (2012), Study and Comparison of Corporation's Governance with Emphasis on Conservatism in Financial Reporting, African Journal of Business Management, 6(2), 587-594.

Nasr, M. A., \& Ntim, C. G. (2018). Corporate governance mechanisms and accounting conservatism: evidence from Egypt. Corporate Governance: The International Journal of Business in Society, 18(3), 386-407.

Pomeroy, B., \& Thornton, D., (2008), Meta-Analysis and the Accounting Literature: The Case of Audit Committee Independence and Financial Reporting Quality, European Accounting Review, 17(2), 305-330.

Reyad, S., (2011), The Role of Audit Committee as a Supportive Tool of Corporate Governance on Enhancing the Quality of Financial Reports an Applied Study on Egyptian Pharmaceutical Corporations, Jordan Journal of Business Administration, 7(1), 43-66.

Richardson, S., Sloan, R., Soliman, M., \& Tuna, A., (2005), Accrual Reliability, Earnings Persistence and Stock Prices, Journal of Accounting and Economics, 39(3), 437-485.

Sarkar, J., \& Sarkar, S., (2009), Multiple Board Appointments and Firm Performance in Emerging Economies: Evidence from India, Pacific-Basin Finance Journal, 17(2), 271293.

Shahen, M., (2010), Study of the Relationship between Corporate Governance and Accounting Conservatism Degree in the Published Financial Statements Application on the Egyptian Stock Exchange, Scientific Journal of Economy and Trade, 4(1), 423-478.

Sharifi, R., Beydokhti, A., \& Masroor, G., (2013), The Study of the Relationship between the Corporate Governance and Conservatism in Financial Reporting in Cement Companies in Tehran Stock Exchange, Journal of Educational and Management Studies, 3(3), 230-234.

Sharma, V., \& Kuang, C., (2014), Voluntary Audit Committee Characteristics, Incentives, and Aggressive Earnings Management: Evidence from New Zealand, International Journal of Auditing, 18(1), 76-89.

Sklar, R. L. (1987). Developmental democracy. Comparative studies in society and history, 29(4), 686-714.

Soliman, M., \& Ragab, A., (2014), Audit Committee Effectiveness, Audit Quality and Earnings Management: An Empirical Study of the Listed Companies in Egypt, Research Journal of Finance and Accounting, 5(2), 155-166.

Suárez, J., García, E., Méndez, C., \& Gutiérrez, C., (2013), The Effectiveness of the Audit Committee in Spain: Implications of its Existence on the Auditor's Opinion, Journal of the Spanish Economic Association, 4(3), 333-352. 
Suijs, J., (2008), On the Value Relevance of Asymmetric Financial Reporting Policies Journal of Accounting Research, 46(5), 1297-1321.

Sultana, N., (2015), Audit Committee Characteristics and Accounting Conservatism, International Journal of Auditing, 19(2), 88-102.

Sun, J., Liu, G., \& Lan, G., (2012), Does Female Directorship on Independent Audit Committees Constrain Earnings Management? Journal of Business Ethics, 99(3), 369-382.

Sun, J., Liu, G., \& Lan, G., (2014), Independent Audit Committee Characteristics and Real Earnings Management, Managerial Auditing Journal, 29(2), 153-172.

Watts, R. L., \& Zuo, L. (2011). Accounting conservatism and firm value: Evidence from the global financial crisis. Working paper at MIT Sloan School of Management. Cambridge, Mass., ZDB-ID 2446924-5. - 4941-11.

Yunos, R., Smith, M., Ismail, Z., \& Ahmad, S. (2011) Inside Concentrated Owners, Board of Directors and Accounting Conservatism, Proceedings of Annual Summit on Business and Entrepreneurial Studies Conference (ASBES 2011), Kuching, Sarawak, Malaysia. 


\section{Table 1}

\section{Sample Selection and Industry Categorization}

\footnotetext{
Notes to Table (1): Table (1) shows the total number of the Egyptian firms available for study during the sample coverage period of 2009 to 2013. Percentage (\%) is the number of the firms included in the sample as a percentage of the total number of the firms being studied (41) with a total of 205 firm-year observations. *Personal and household products sector is the highest representation in the sample with a percentage of $19.5 \%$.

** Real estate sector is the second represented sector in the sample with a $14.5 \%$.

***Oil and Gas, Media, and technology sectors are the lowest representation in the sample with a $2.5 \%$ percent of the total number.

Banks and financial services are excluded as different regulations and governance guidelines are imposed on such institutions. They represent different per industry nature which may affect the results.
}

\section{Panel A: Sample Selection}

Total firms in the EGX 50

50

250

Less: Banks sector

1

5

Less: financial services sector

8

40

Final sample used for the Egyptian Companies over the period 2009 to 2013

41

205

\section{Panel B: Sample Distribution by Industry}

\begin{tabular}{lccc}
\hline \multicolumn{1}{c}{ Industry } & \# firms & \# Obs. & \% Obs. \\
\hline Basic Resources & 4 & 20 & $9.7 \%$ \\
chemicals & 3 & 15 & $7.5 \%$ \\
Oil \& Gas & 1 & 5 & $2.5 \%$ \\
Personal \& Household products & 8 & 40 & $19.5 \% *$ \\
Food \&beverages & 4 & 20 & $9.7 \%$ \\
telecommunications & 3 & 15 & $7.5 \%$ \\
Industrial Goods \& Services & 4 & 20 & $9.7 \%$ \\
Travel \& leisure & 2 & 10 & $5 \%$ \\
Media & 1 & 5 & $2.5 \%$ \\
Real Estate & 6 & 30 & $14.5 \% * *$ \\
Construction \& Materials & 4 & 20 & $9.7 \%$ \\
Technology & 1 & 5 & $2.5 \% *$ \\
Total & 41 & 205 & $100 \%$ \\
\hline
\end{tabular}


Table 2

\section{Descriptive Statistics and Univariate Analysis}

Notes to Table (2): Table (2) displays the descriptive statistics and Univariate Analysis of the final sample of firms used in the statistical analysis. Panel A presents the descriptive statistics of the full sample of 205 obs. and Panel $\mathrm{B}$ displays the univariate analysis of the mean differences for firms with Hi Governance Score as measured by firms with Gov_SC higher than the sample median vs. firms with Low Governance Score as measured by firms with Gov_SC below the sample median. *significant at $0.05, * *$ significant at $0.01, * * *$ significant at 0.001

Panel A: Descriptive Statistics of the Full Sample

\begin{tabular}{lcccc}
\hline & Minimum & Maximum & Mean & Std. Deviation \\
\cline { 2 - 5 } CON_ACCR & -0.1295 & 0.0940 & 0.0027 & 0.0273 \\
CON_AT & -0.0254 & 0.0906 & 0.0050 & 0.0194 \\
AC_IND & 0.3333 & 1.5000 & 0.8721 & 0.2095 \\
AC_EXP & 0.1250 & 1.0000 & 0.4841 & 0.2396 \\
AC_DIL & 2.0000 & 12.0000 & 4.7463 & 1.7668 \\
AC_SIZE & 2.0000 & 6.0000 & 3.3707 & 0.8627 \\
AC_MULTI & 0.0000 & 5.0000 & 2.1805 & 1.3690 \\
REV & 0.0000 & 1.0000 & 0.4000 & 0.4911 \\
LEV & 0.0172 & 7.9582 & 1.3327 & 1.4455 \\
AUD & 0.0000 & 1.0000 & 0.5756 & 0.4955 \\
PROF & -0.2789 & 0.3907 & 0.0675 & 0.1023 \\
LIT & 0.0000 & 1.0000 & 0.0976 & 0.2974 \\
SIZE & 0.9103 & 1.0348 & 0.9762 & 0.0302 \\
MTB & -3.0989 & 9.8673 & 1.5045 & 1.7501 \\
\hline
\end{tabular}

Panel B: Univariate Analysis of Firm of Hi vs. Low Governance Index

\begin{tabular}{lllll}
\hline & Gov_SC $=1$ & Gov_SC $=0$ & Diff_Means & t-test \\
\hline CON_ACCR & 0.0033 & -0.0013 & 0.0046 & 0.7716 \\
CON_AT & 0.0051 & 0.0042 & 0.0008 & 0.2011 \\
AC_IND & 0.8909 & 0.7302 & 0.1607 & $3.6348^{* * *}$ \\
AC_EXP & 0.4925 & 0.4205 & 0.0720 & 1.3870 \\
AC_DIL & 4.7459 & 4.7500 & -0.0041 & -0.0108 \\
AC_SIZE & 3.3204 & 3.7500 & -0.4296 & $-2.3165^{* * *}$ \\
AC_MULTI & 2.2707 & 1.5000 & 0.7707 & $2.6289^{* * *}$ \\
REV & 0.3812 & 0.5417 & -0.1605 & -1.5087 \\
LEV & 1.3850 & 0.9380 & 0.4471 & 1.4274 \\
AUD & 0.6243 & 0.2083 & 0.4160 & $4.0047^{* * *}$ \\
PROF & 0.0631 & 0.1002 & -0.0371 & $-1.6745^{*}$ \\
LIT & 0.1050 & 0.0417 & 0.0633 & 0.9796 \\
SIZE & 0.9781 & 0.9613 & 0.0169 & $2.6021^{* *}$ \\
MTB & 1.4622 & 1.8234 & -0.3612 & -0.9499 \\
\hline
\end{tabular}


Table 3

\section{Pearson and Spearman Correlation Matrices}

Notes to Table (3): Table (3) displays the correlation matrices. The upper diagonal matrix presents the Pearson Correlation and the lower diagonal displays the Spearman Correlation. $* * *, * * *$. Correlation is significant at the $0.01,0.05$, and 0.10 level respectively (2-tailed).

\begin{tabular}{|c|c|c|c|c|c|c|c|c|c|c|c|c|c|c|}
\hline \multirow{15}{*}{ 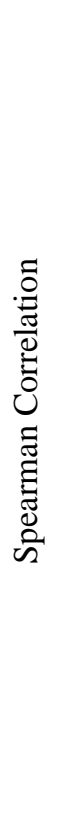 } & & \multicolumn{13}{|c|}{ Pearson Correlation } \\
\hline & & CON_ACCR & CON_AT & AC_IND & AC_EXP & AC_DIL & AC_SIZE & AC_MULTI & LEV & AUD & PROF & LIT & SIZE & MTB \\
\hline & CON_ACCR & & $.208^{* * * *}$ & -0.005 & 0.066 & -0.079 & -0.053 & -0.100 & 0.056 & 0.026 & $-.424^{* *}$ & -0.072 & -0.057 & $.227^{* * *}$ \\
\hline & CON_AT & $.163^{* *}$ & & $.199^{* * * *}$ & $.199^{* * *}$ & $.424^{* * * *}$ & $.181^{* * *}$ & 0.035 & $.722^{* * *}$ & $.146^{* *}$ & 0.012 & $0.131^{*}$ & $.328^{* * *}$ & $.874^{* * *}$ \\
\hline & AC_IND & $-0.119^{*}$ & $.188^{* * *}$ & & 0.091 & -0.013 & -0.037 & $.140^{* *}$ & 0.096 & $.464^{* * *}$ & 0.018 & 0.133 & $.209^{* * *}$ & 0.049 \\
\hline & AC_EXP & 0.033 & $.183^{* * *}$ & 0.031 & & 0.013 & -0.075 & 0.002 & $.138^{* *}$ & $.255^{* * *}$ & -0.103 & 0.007 & -0.077 & 0.077 \\
\hline & AC_DIL & -0.099 & $.260^{* * * *}$ & -0.104 & -0.057 & & $.409^{* * *}$ & $.185^{* * *}$ & $.329^{* * * *}$ & -0.084 & $.339^{* * *}$ & $.318^{* * *}$ & $0.122^{*}$ & $.479^{* * * *}$ \\
\hline & AC_SIZE & -0.047 & 0.094 & $-0.127^{*}$ & -0.098 & $.360^{* * * *}$ & & $.350^{* * * *}$ & 0.108 & $-.307^{* * *}$ & $.209^{* * *}$ & 0.088 & -0.067 & $.303^{* * *}$ \\
\hline & AC_MULTI & -0.115 & 0.063 & 0.084 & -0.028 & $.203^{* * *}$ & $.350^{* * *}$ & & 0.115 & $.222^{* * *}$ & $.220^{* * *}$ & $.486^{* * *}$ & $.345^{* * *}$ & -0.034 \\
\hline & LEV & $0.126^{*}$ & $.624^{* * *}$ & 0.029 & $.217^{* * *}$ & 0.059 & -0.017 & 0.103 & & $.228^{* * *}$ & -0.088 & $.251^{* * *}$ & $.410^{* * *}$ & $.588^{* * *}$ \\
\hline & AUD & -0.004 & $.344^{* * *}$ & $.470^{* * *}$ & $.219^{* * *}$ & -0.024 & $-.319^{* * *}$ & $.189^{* * * *}$ & $.344^{* * *}$ & & 0.000 & $.249^{* * *}$ & $.458^{* * *}$ & -0.044 \\
\hline & PROF & $-.405^{* * *}$ & 0.106 & -0.020 & -0.050 & $.240^{* * * *}$ & 0.093 & $.221^{* * *}$ & -0.094 & 0.023 & & $.155^{* *}$ & $0.123^{*}$ & 0.067 \\
\hline & LIT & -0.106 & 0.100 & $.137^{* *}$ & -0.033 & $.328^{* * * *}$ & 0.102 & $.474^{* * *}$ & 0.116 & $.249^{* * *}$ & $.212^{* * *}$ & & $.292^{* * *}$ & 0.058 \\
\hline & SIZE & -0.081 & $.436^{* * *}$ & 0.135 & -0.063 & $.153^{* *}$ & -0.103 & $.333^{* * *}$ & $.401^{* * * *}$ & $.433^{* * *}$ & $.189^{* * *}$ & $.276^{* * *}$ & & 0.046 \\
\hline & MTB & $.155^{* *}$ & $.766^{* * * *}$ & 0.079 & 0.112 & $.337^{* * * *}$ & $.254^{* * * *}$ & -0.036 & $.346^{* * * *}$ & 0.135 & $.173^{* *}$ & -0.024 & 0.047 & \\
\hline
\end{tabular}


Table 4

\section{Regression Model for Khan and Watts (2009) Conservatism Measure}

Notes to Table (4): Table (4) presents the results of the regression of asymmetric timeliness as a measure of accounting conservatism on determinants of asymmetric timeliness as in Khan and Watts (2009). where: D is a dummy variable equal to 1 if returns $(\mathrm{R})$ are negative and 0 if returns are positive; SIZE is the natural log of firms' total assets; MTB is the market-to-book ratio; Lev is leverage, defined as long term debt deflated by market value of equity. *significant at 0.10 , **significant at 0.05 , $* * *$ significant at 0.01 (2-tailed).

\begin{tabular}{lccc}
\hline Independent Variables & Predicted Sign & Coefficient & T-Stat \\
\hline (Constant) & $?$ & 0.088 & $9.363^{* * *}$ \\
D & + & -0.013 & -0.982 \\
R & - & 0.073 & $1.002^{*}$ \\
R_SIZE & + & -0.005 & $-0.663^{*}$ \\
R_MTB & - & -0.001 & -0.112 \\
R_LEV & + & -0.011 & $-2.559^{*}$ \\
DR & + & 0.155 & $1.458^{*}$ \\
DR_SIZE & - & 0.013 & $1.129 *$ \\
DR_MTB & + & 0.021 & $1.498^{*}$ \\
DR_LEV & + & 0.007 & $1.046^{*}$ \\
R square & & 0.113 & \\
& + & &
\end{tabular}




\section{Table 5}

\section{Regression of Asymmetric Timeliness measure of Conservatism (CON_AT) on Audit Committee Characteristics}

Notes to Table (5): Table (5) presents the results of the regression of asymmetric timeliness as a measure of accounting conservatism (CON_AT) on determinants of corporate governance characteristics and control variables. where: Model (1) displays the results on the association between CON_AT and Audit Committee Independence (AC_IND). Model (2) presents the results on the association between CON_AT and Audit Committee Independence (AC_IND) and Expertise (AC_EXP). Model (3) presents the results on the association between CON_AT and Audit Committee Independence (AC_IND), Expertise (AC_EXP), and Diligence (AC_DIL). Model (4) presents the results on the association between CON_AT and Audit Committee Independence (AC_IND), Expertise (AC_EXP), Diligence (AC_DIL), and Size (AC_SIZE). Model (5) presents the results on the association between CON_AT and Audit Committee Independence (AC_IND), Expertise (AC_EXP), Diligence (AC_DIL), Size (AC_SIZE), and Multi-Directorship (AC_MULTI). *significant at 0.10, **significant at 0.05, ***significant at 0.01 (1-tailed).

\begin{tabular}{|c|c|c|c|c|c|c|c|c|c|c|c|}
\hline \multirow[b]{2}{*}{$\begin{array}{l}\text { Independent } \\
\text { Variables }\end{array}$} & \multirow[b]{2}{*}{$\begin{array}{c}\text { Predicted } \\
\text { Sign }\end{array}$} & \multicolumn{2}{|c|}{ Model (1) } & \multicolumn{2}{|c|}{ Model (2) } & \multicolumn{2}{|c|}{ Model (3) } & \multicolumn{2}{|c|}{ Model (4) } & \multicolumn{2}{|c|}{ Model (5) } \\
\hline & & Coeff. & T-Stat & Coeff. & T-Stat & Coeff. & T-Stat & Coeff. & T-Stat & Coeff. & T-Stat \\
\hline (Constant) & $?$ & -0.0229 & $-2.13 * *$ & -0.0338 & $-3.01 * * *$ & -0.0475 & $-4.32 * * *$ & -0.0520 & $-4.63 * * *$ & -0.0539 & $-4.83 * * *$ \\
\hline AC_IND & + & 0.0276 & $3.41 * * *$ & 0.0306 & $3.82 * * *$ & 0.0253 & $3.31 * * *$ & 0.0232 & $3.01 * * *$ & 0.0219 & $2.86 * * *$ \\
\hline AC_EXP & + & & & 0.0160 & $2.85 * * *$ & 0.0143 & $2.69 * * *$ & 0.0133 & $2.49 * * *$ & 0.0123 & $2.32 * *$ \\
\hline AC_DIL & + & & & & & 0.0041 & $4.80 * * *$ & 0.0036 & $3.98 * * *$ & 0.0034 & $3.81 * * *$ \\
\hline AC_SIZE & + & & & & & & & 0.0030 & $1.75 * *$ & 0.0047 & $2.52 * * *$ \\
\hline AC_MULTI & $?$ & & & & & & & & & -0.0026 & $-2.14 * * *$ \\
\hline AUD & + & -0.0089 & $-2.46 * * *$ & -0.0126 & $-3.31 * * *$ & -0.0059 & $-1.55^{*}$ & -0.0038 & -0.96 & -0.0011 & -0.25 \\
\hline PROF & + & 0.0166 & 1.03 & 0.0226 & $1.42 *$ & 0.0059 & 0.38 & 0.0027 & 0.17 & 0.0111 & 0.70 \\
\hline Industry-Effect & & Included & & Included & & Included & & Included & & Included & \\
\hline Fixed-Effect & & Included & & Included & & Included & & Included & & Included & \\
\hline Adj. R Sq. & & 0.225 & & 0.254 & & 0.334 & & 0.341 & & 0.354 & \\
\hline F-Ratio & & 4.124 & & 4.470 & & 5.870 & & 5.800 & & 5.800 & \\
\hline P-Value & & $<0.000$ & & $<0.000$ & & $<0.000$ & & $<0.000$ & & $<0.000$ & \\
\hline
\end{tabular}




\section{Table 6}

\section{Regression of the Changes of Asymmetric Timeliness measure of Conservatism (CON_AT) on the Interaction between Audit Committee Characteristics and the Egyptian Revolution}

Notes to Table (6): Table (6) presents the results of the regression of the changes ( $\Delta$ CON_AT) of Asymmetric Timeliness as measures of accounting conservatism on the interaction between Audit Committee characteristics and the Egyptian Revolution (REV). Other control variables, industry and firm-fixed effects are also included in the models. REV and REV_GOV are highly correlated, therefore, only REV_GOV is included in the model. Model (1) displays the results on the association between CON_AT and the interaction between Audit Committee characteristics (AC_IND, AC_EXP, AC_DIL, AC_SIZE, AC_MULTI) and the Egyptian Revolution (REV). Model (2) displays the results on the association between $\triangle \mathrm{CON}$ _AT and the interaction between Audit Committee characteristics (AC_IND, AC_EXP, AC_DIL, AC_SIZE, AC_MULTI) and the Egyptian Revolution (REVOLT). The variables of interest in models (1) \& (2) are the interaction terms (AC_IND_REV, AC_EXP_REV, AC_DIL_REV, AC_SIZE, REV, \& AC_MULTI_REV). *significant at $0.10, * *$ significant at $0.05, * * *$ significant at 0.01 (1-tail).

\begin{tabular}{|c|c|c|c|c|c|}
\hline \multirow[b]{2}{*}{ Independent Variables } & \multirow[b]{2}{*}{ Predicted Sign } & \multicolumn{2}{|c|}{ Model (1) } & \multicolumn{2}{|c|}{ Model (2) } \\
\hline & & Coeff. & T-Stat & Coeff. & T-Stat \\
\hline (Constant) & $?$ & -0.2044 & $-46.25 * * *$ & -0.5995 & $-17.24 * * *$ \\
\hline AC_IND_REV & + & 0.1078 & $42.35^{* * *}$ & 0.3579 & $11.10 * * *$ \\
\hline AC_EXP_REV & + & 0.0033 & $2.45^{* * *}$ & -0.0013 & -0.06 \\
\hline AC_DIL_REV & + & 0.0283 & $50.73 * * *$ & 0.0651 & $14.78 * * *$ \\
\hline AC_SIZE_REV & - & -0.0548 & $-46.49 * * *$ & -0.1218 & $-12.74 * * *$ \\
\hline AC_MULTI_REV & + & 0.0471 & $43.32 * * *$ & 0.1124 & $12.87 * * *$ \\
\hline AC_IND & + & -0.0024 & -1.21 & -0.1237 & $-5.39 * * *$ \\
\hline AC_EXP & + & 0.0883 & $64.15^{* * *}$ & 0.1673 & $15.44 * * *$ \\
\hline AC_DIL & + & 0.0016 & $8.27 * * *$ & -0.0150 & $-8.06^{* * *}$ \\
\hline AC_SIZE & + & 0.0255 & $33.63 * * *$ & 0.0782 & $10.47 * * *$ \\
\hline AC_MULTI & - & -0.0380 & $-58.11 * * *$ & -0.0971 & $-15.28 * * *$ \\
\hline GOV_SC & + & -0.0178 & $-35.41 * * *$ & -0.0330 & $-8.39 * * *$ \\
\hline AUD & + & -0.0296 & $-52.65^{* * *}$ & -0.0625 & $-11.62 * * *$ \\
\hline PROF & + & -0.0111 & $-5.84 * * *$ & -0.2242 & $-10.69^{* * *}$ \\
\hline Industry-Effect & & Included & & Included & \\
\hline Fixed-Effect & & Included & & Included & \\
\hline Adj. R Sq. & & 0.99 & & 0.97 & \\
\hline F-Ratio & & 1887.02 & & 190.62 & \\
\hline P-Value & & $<0.000$ & & $<0.000$ & \\
\hline
\end{tabular}




\section{Table 7 \\ Regression of the Levels of Asymmetric Timeliness measure of Conservatism (CON_AT) on the Interaction between Audit Committee Characteristics and the Egyptian Revolution}

Notes to Table (7): Table (7) presents the results of the regression of the level (CON_AT) of Asymmetric Timeliness as measures of accounting conservatism on the interaction between Audit Committee Index and the Egyptian Revolution (REV). Other control variables, industry and firm-fixed effects are also included in the models. Model (1) displays the results on the association between CON_AT and the interaction between Audit Committee Index (GOV_SC) and the Egyptian Revolution (REV). Model (2) displays the results on the association between $\Delta$ CON_AT and the interaction between Audit Committee Index (GOV_SC) and the Egyptian Revolution (REV). REV and REV_GOV are highly correlated, therefore, only REV_GOV is included in the model. The variable of interest in models (1) \& (2) is the interaction term (REV_GOV). *significant at 0.10 , **significant at 0.05 , ***significant at 0.01 (1-tail).

\begin{tabular}{|c|c|c|c|c|c|}
\hline \multirow[b]{2}{*}{ Independent Variables } & \multirow[b]{2}{*}{$\begin{array}{c}\text { Predicted } \\
\text { Sign }\end{array}$} & \multicolumn{2}{|c|}{ Model (1) } & \multicolumn{2}{|c|}{ Model (2) } \\
\hline & & Coeff. & T-Stat & Coeff. & T-Stat \\
\hline (Constant) & $?$ & 0.0126 & 0.87 & -0.0791 & $-1.80 * *$ \\
\hline REV_GOV & + & -0.0011 & -0.28 & 0.0161 & $1.38 *$ \\
\hline GOV_SC & + & -0.0018 & -0.71 & -0.0047 & -0.59 \\
\hline AUD & + & -0.0006 & -0.20 & -0.0185 & $-1.92 * *$ \\
\hline PROF & + & 0.0056 & 0.34 & -0.0538 & -1.06 \\
\hline Industry-Effect & & Included & & Included & \\
\hline Fixed-Effect & & Included & & Included & \\
\hline Adj. R Sq. & & 0.178 & & 0.075 & \\
\hline F-Ratio & & 3.20 & & 1.822 & \\
\hline P-Value & & $<0.000$ & & $<0.021$ & \\
\hline
\end{tabular}

